\title{
MAGNIFYING ENDOSCOPY OF THE DUODENUM WITH DYE SCATTERING METHOD IN A CASE WITH CELIAC DISEASE
}

\author{
Tetsuo MORISHITA ${ }^{1}$, Toshiaki KAMIYA ${ }^{2}$ and Hiromasa ISHII $^{3}$
}

\begin{abstract}
Aim - To know the more detailed findings of the small intestinal mucosa with the use of a magnifying endoscope and a vital dye, and the efficacy of the both tools. Patient and Methods - A 54-year old female patient with celiac disease. The duodenal mucosa downward as far as the descending portion was observed with a magnifying endoscope (Olympus GIF HM) before and after spraying the mucosa with $0.1 \%$ indigo carmine. Results - The endoscopy clarified the atrophy and edema of each villus, and scattering of the dye revealed shorter villi with the relatively longer villi remaining in islands. Conclusion - The combination of magnifying endoscopy and the dye scattering method is useful for closer observation of the intestinal mucosa in celiac diseases.
\end{abstract}

HEADINGS - Duodenoscopy. Duodenoscopes. Dyes. Celiac disease.

\section{INTRODUCTION}

There have been several papers on the effectiveness of conventional duodenal endoscopy in the diagnosis of celiac diseases $^{(1,2,5,10,11,14)}$. Availability of the magnifying endoscope $^{(12,13)}$ and the dye scattering $\operatorname{method}^{(7)}$ have made it possible to observe the mucosa in intricate detail. This paper suggests the efficacy of the combination of magnifying endoscopy and the indigo carmine scattering method in a patient with celiac disease.

\section{CASE REPORT}

A 54-year-old white female from Canada, who had been living in Shizuoka, Japan for 2 years, complained of watery diarrhea three times a day for the previous month. She showed significant weight loss, $4 \mathrm{~kg}$ over a month, and felt exhausted. Although she denied ever having suffered from any diarrheal disease as a child, she developed intractable diarrhea immediately after giving birth at the age of 26 to her first child. At that time she was examined with the use of a barium enema and was diagnosed as having "colitis". Though she responded to treatment with an oral corticosteroid, her stool had become soft since then. One year prior to her moving to Shizuoka she was diagnosed as having iron-deficiency anemia, during the course of a hysterectomy for uterine prolapse at a hospital in Kyoto. Physical examination revealed a $170 \mathrm{~cm}$ tall, thin $(52.5 \mathrm{~kg})$ female with pretibial edema and finger-clubbing. Atypical skin lesions suggesting dermatitis herpetiformis were not seen. No superficial lymph nodes were palpable. The laboratory data showed hypoalbuminemia $(2.9 \mathrm{~g} / \mathrm{dL})$, hypocholesterolemia $(124 \mathrm{mg} / \mathrm{dL})$ and mild liver dysfunction (GOT 116, GPT 72). Serum carotene $(26 \mu / d L)$, folate $(1.5 \mathrm{ng} / \mathrm{mL})$, and iron $(65 \mu / \mathrm{dL})$ were also low, and prothrombin time (19.6 sec, 30\%) was significantly prolonged. Serum IgA (613 mg/dL) was abnormally high. The Sudan stain test for stool was positive. The normal rise in blood sugar was not observed during the glucose tolerance test, and the $25 \mathrm{~g}$ D-xylose test was abnormal (2.8 g/5 h).

${ }^{1}$ Department of Internal Medicine, Tokyo Dental College, Chiba, Japan; ${ }^{2}$ Department of Gastroenterology, School of Medicine, Christian University of Bolivia, Santa Cruz, Bolivia; ' Department of Internal Medicine, School of Medicine, Keio University, Tokyo, Japan

Address for correspondence: Tetsuo Morishita, MD - Department of Internal Medicine - Tokyo Dental College - 5-11-13 Sugano, Ichikawa-shi, Chiba - 2728513 - Japan. e-mail: tmorishi@tdc.ac.jp 
Barium examination of the small intestine revealed the so-called "malabsorption pattern", i.e. dilatation of the small intestine, thickening of the mucosal folds, segmentation of the ileum, and flocculation of the barium.

Magnifying endoscopy of the upper gastrointestinal tract was performed following the patient's informed consent. After the patient fasted, the duodenal mucosa was visualized through a magnifying fiberendoscope (Olympus GIF HM) ${ }^{(12,13)}$, inserted downward as far as the descending portion of the duodenum. Without magnification, the entire bulbus showed a flat mucosal pattern with reddened spots located immediately below the pylorus ring (Figure 1 left). The mucosa showed a mosaic pattern with edema and a reduction in number of Kerckring's folds in the descending portion (Figure 1 right). Under lower magnification, about $x 20$, the mucosa showed unevenness of its surface with minute nodules (Figure 2). Under higher magnification, the villi seemed to be fused with each other (Figure 3 left, about x30) and each

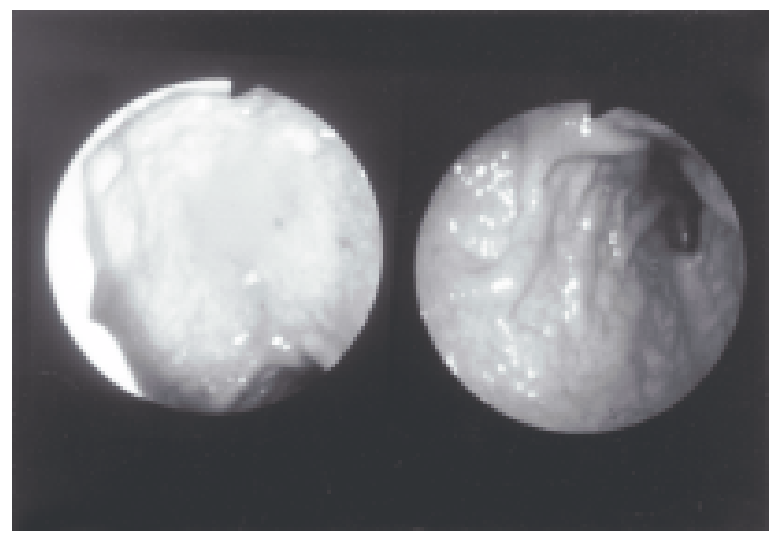

FIGURE 1 - The endoscopy without magnification shows a flat mucosa with reddened spots in the bulbus (left) and a mosaic pattern with edema and decreased Kerckring's folds in the descending portion of the duodenum (right).

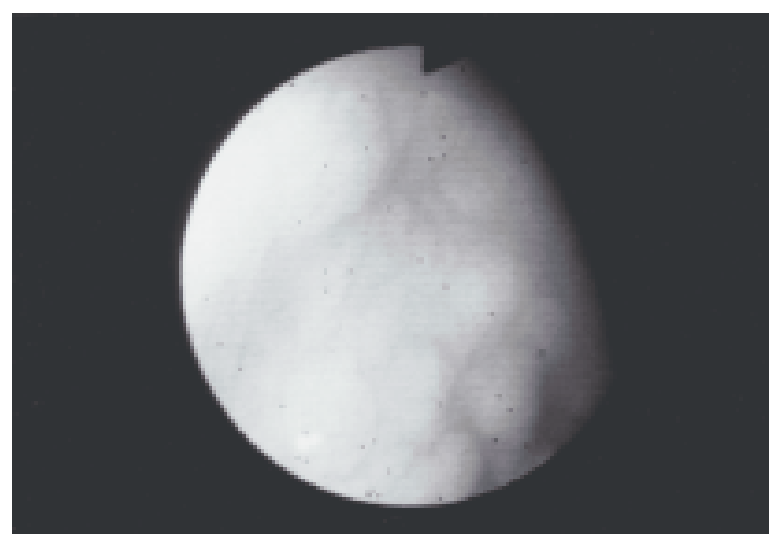

FIGURE 2 - Unevenness of the mucosal surface with minute nodules observed with magnification $\mathrm{x} 20$. villus was flat and edematous with an indistinct margin (Figure 3 right, about $x 40$ ). After spraying the mucosa with $0.1 \%$ indigo carmine, good contrast was obtained in the mucosal unevenness. The mucosa was extensively flattened; the shorter villi lay flat while the relatively longer villi remained in islands (Figure 4, about x10).

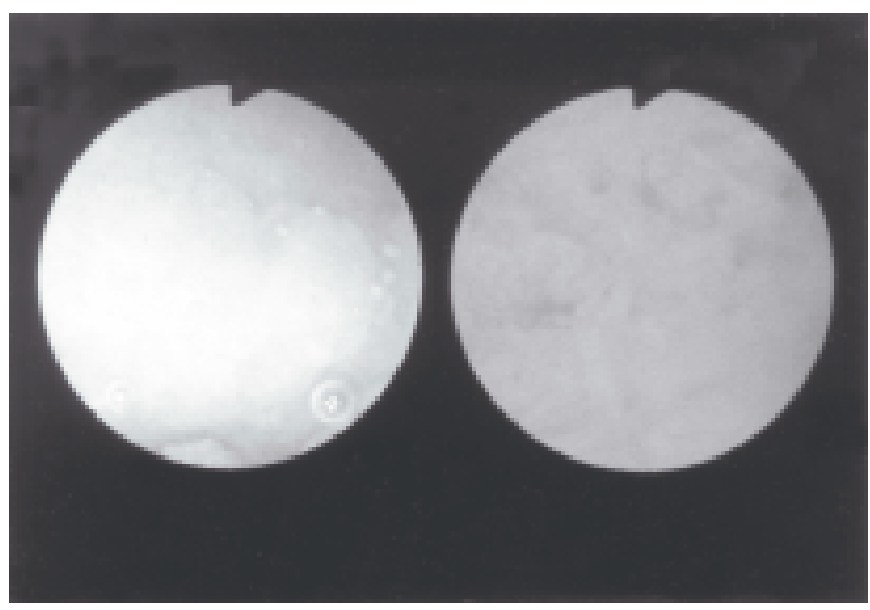

FIGURE 3 - The villi appear to be fused (left, x30) and each villus was flat and edematous (right, $\mathrm{x} 40$ ).

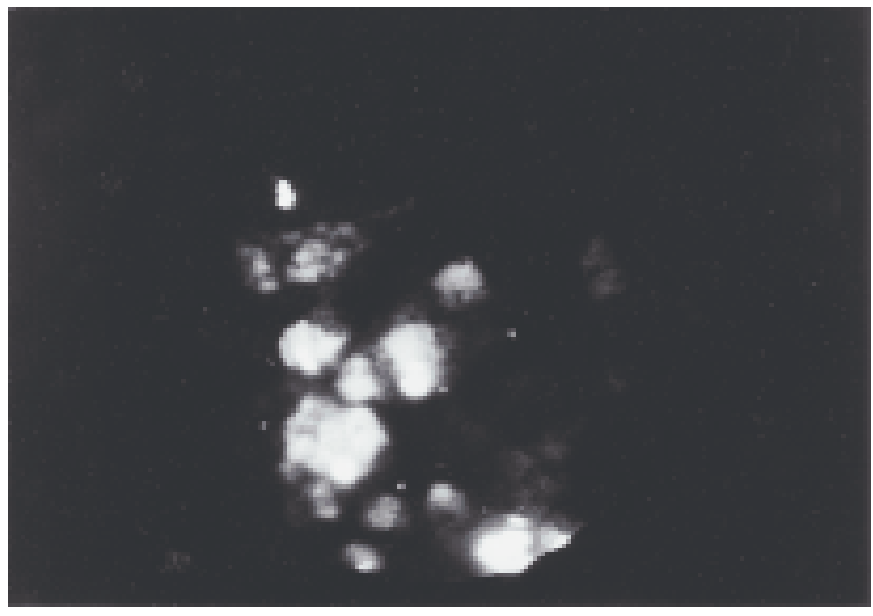

FIGURE 4 - The relatively longer villi remain in islands in the sea of the dye over the shorter villi after spraying of indigo carmine (x10).

Biopsy revealed subtotal villous atrophy accompanied by increased cellular infiltrate with plasma cells and lymphocytes in the lamina propria (Figure 5a, x100). Epithelial cells were somewhat cuboidal, and the number of intraepithelial lymphocytes was markedly increased (Figure 5b, x200). Abdominal US and CT scan showed mild hepatomegaly and splenic atrophy without enlargement of the lymph nodes. 
A

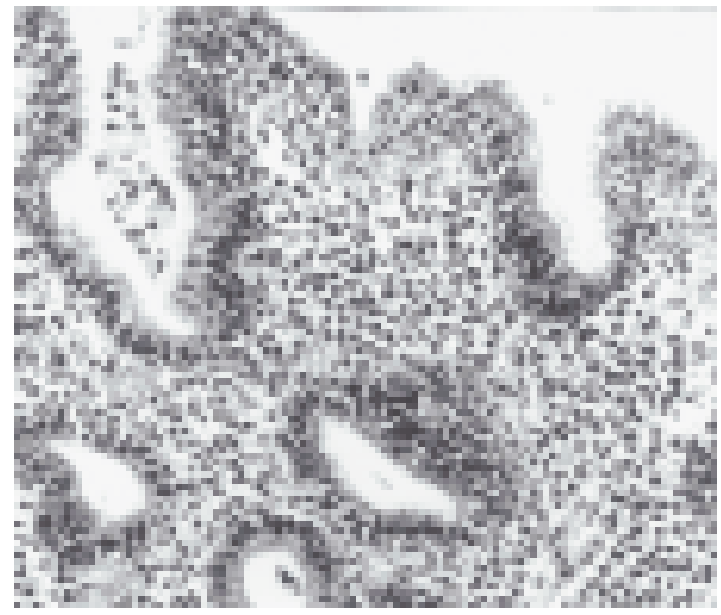

B

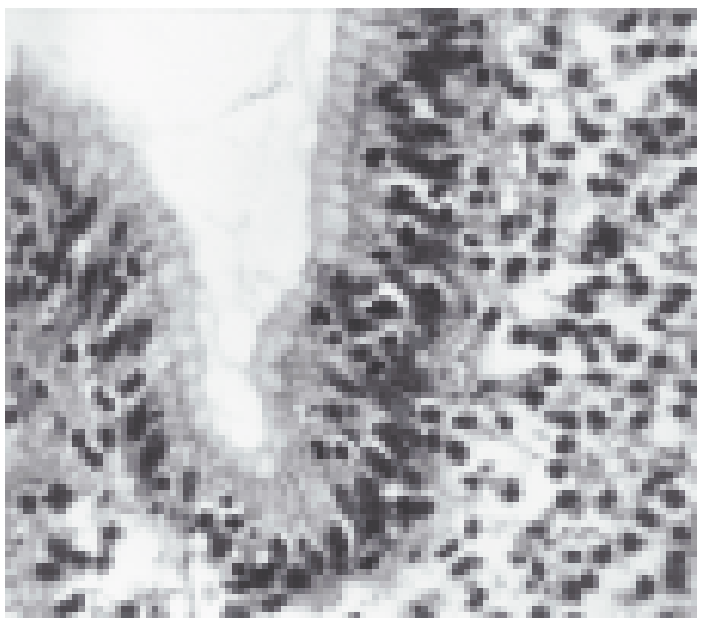

FIGURE 5 - Biopsy specimen reveals subtotal villous atrophy with cellular infiltrate (5A, x100) and cuboidal epithelial cells and intraepithelial lymphocytes $(5 \mathrm{~B}, \mathrm{x} 200)$.

Further evaluation disclosed an increased level of antigliadin antibodies of $\operatorname{IgG}$ and $\operatorname{IgA}$ isotypes. Tissue typing in the patient detected the HLA antigens B8, DR3 and DR7.

The patient was diagnosed as having celiac disease, and was immediately placed on a strict gluten-free diet. Within a week her bowel habits improved, and she began to regain her energy. Her laboratory results returned toward normal. Her weight increased dramatically, and she gained $12 \mathrm{~kg}$ in 5 months.

\section{DISCUSSION}

Celiac disease is one of the major cause of malabsorption in the west. The prevalence is 1:250-300 in western countries ${ }^{(15)}$. In contrast with the high incidence of the disease among whites, there have been very few cases among the Japanese. Six cases of celiac disease have been reported by endoscopists ${ }^{(4,6,8,16,17,20)}$ in Japan.

Celiac disease is now understood to be a disorder with a wide range of presenting manifestations of variable severity, as well as the classic malabsorptive symptoms of diarrhea and weight loss. Over $50 \%$ of patients with celiac disease have no gastrointestinal symptoms. Less than $50 \%$ present with diarrhea. One fifth are underweight and $1 / 3$ are overweight. Glossitis, angular stomatitis, dental enamel defects, hair loss, calcium and vitamin D malabsorption, neurologic syndromes, reduced fertility and anemia have been reported in patients with celiac disease.

Celiac disease is associated with IgA deficiency, diabetes mellitus, thyroid disease, dermatitis herpetiformis, primary biliary cirrhosis and autoimmune hepatitis ${ }^{(15)}$.

Endoscopy of the duodenum and endoscopic biopsy are useful tools for the diagnosis of celiac disease. The endoscopic markers of the small intestine, such as loss or decrease of duodenal folds, a mosaic pattern, scalloping of the folds in the descending portion ${ }^{(1,5,10,11,14)}$ and multiple lesions with a prominent and roundish aspect in the bulb have been identified.

In this paper, we reported on the magnified endoscopic images of the duodenum in addition to staining with a dye.

Magnifying endoscopy revealed the atrophy and edema of each villus, showing flat and uneven mucosa with minute nodules. Only one report has appeared on the use of magnifying endoscopy of the intestinal tract in celiac disease. HIRATSUKA et al ${ }^{(4)}$ reported on the mucosal changes of the terminal ileum using the Machida magnifying endoscope for the small intestine, FIS-MS III (maximum magnification $\mathrm{x} 30$, depth of field $2 \mathrm{~mm} \sim \infty$ ). They described the fusion of atrophic villi forming edematous sausage-like protrusions. It is not yet known if our magnifying endoscopic findings are typical or not for celiac disease, because they have not been described in other diseases. GILLBERG and AHRÉN ${ }^{(3)}$ observed the duodenal villous atrophy on a close-up view with an Olympus GIF type D2 (depth of view field $5 \mathrm{~mm} \infty$ by reducing the focal length of the viewing lens. No paper on the utility of magnifying endoscopy for the early diagnosis of celiac disease has been reported.

The indigo carmine dye scattering method ${ }^{(7)}$ made clearer the mucosal change observed with the magnifying endoscopy, especially the unevenness. STEVENS and McCARTHY ${ }^{(18)}$ reported that severe atrophy of the mucosal surface could be demonstrated throughout the duodenal cap using indigo carmine scattering with an Olympus GIF type D2 endoscope.

Magnifying endoscopy is useful for the observation of fine mucosal patterns and the detection of minute mucosal lesions ${ }^{(12,13)}$. By magnifying the image of the duodenal mucosa, minute morphological changes of the villi can be clearly observed. The endoscopic magnifying method permits direct visual in vivo inspection of the individual villi with comparable resolution to a dissecting microscope ${ }^{(19)}$. Furthermore, 
the method may make the early detection of mucosal changes possible, and present a morphological classification of the changes. For example, the diagnostic classification of colorectal tumorous lesions was made based on the pit patterns of the mucosa seen with magnifying colonoscopy coupled with indigo carmine and cresyl violet staining ${ }^{(20)}$. The combination of the magnifying and dye scattering methods is effective for more-advanced diagnostic study of the intestinal mucosa in patients with celiac disease.

\section{ACKNOWLEDGEMENT}

The authors are indebted to late Dr. Masaharu Tsuchiya (Keio University, Japan) and Dr. Hitoshi Asakura (Niigata University, Japan) for their guidance, and to Dr. Koushi Ando (Hamamatsu Red Cross Hospital, Japan), Dr. Atsuko Morishita (Tokyo Dental College Ichikawa General Hospital, Japan) and Ms. Wendy Lenner (Calgary, Canada) for their assistance.

Morishita T, Kamiya T, Ishii H. Endoscopia com magnificação e coloração por dispersão no duodeno em paciente com doença celíaca. Arq Gastroenterol 2003;40(2):110-113.

RESUMO - Objetivos - Ampliar os achados na mucosa intestinal com o uso da endoscopia com magnificação e coloração ao vivo e verificar a eficácia de ambos os métodos. Paciente e Métodos - Paciente de 54 anos, do sexo feminino, com doença celíaca. Observou-se a mucosa duodenal mais distal possível com endoscópio com magnificação (Olympus GIF HM), antes e depois da dispersão por jato de índigo carmim a $0,1 \%$. Resultados - A endoscopia acentuou a atrofia e o edema dos vilos, e a dispersão do corante revelou vilos longos, remanescentes em ilhas, em meio a vilos encontrados. Conclusão A combinação da endoscopia com magnificação e a coloração por dispersão mostrou-se método útil para observação próxima da mucosa intestinal na doença celíaca.

DESCRITORES - Duodenoscopia. Duodenoscópios. Tinturas. Doença celíaca.

\section{REFERENCES}

1. Brocchi E, Corazza GR, Caletti G, Treggiari EA, Barbara L, Gasbarrini G. Endoscopic demonstration of loss of duodenal folds in the diagnosis of celiac disease. N Eng J Med 1988;319:741-4.

2. Brocchi E, Corazza GR, Brusco G, Mangia L, Gasbarrini G. Unsuspected celiac disease diagnosed by endoscopic visualization of duodenal bulb micronodules. Gastrointest Endosc 1996;44:610-1.

3. Gillberg R, Ahrén C. Coeliac disease diagnosed by means of duodenoscopy and endoscopic duodenal biopsy. Scand J Gastroenterol 1977;12:911-6.

4. Hiratsuka H, Gocho K, Tanaka M. Examination of the magnified mucosal surface and pathological changes of the human intestine. Stomach and Intestine, 1978;13:615-24.

5. Jabbari M, Wild G, Goresky CA, Daly DS, Lough JO, Cleland DP, Kinnear DG Scalloped valvulae conniventes: an endoscopic marker of celiac sprue. Gastroenterology 1988;95:1518-22.

6. Kihara T, Kukida S, Ichikawa Y. Ultrastructual studies of the duodenal epithelium of Japanese celiac sprue. J Clin Electron Microscopy 1977;10:383-4.

7. Kohli Y, Nakajima M, Ida K. Minute endoscopic findings of duodenal mucosa using the dye scattering method. Endoscopy 1974;6:1-6.

8. Kosaka K, Kihara T, Ueda K. Per oral biopsy of the intestinal mucosa. Naika 1961;7:1061-6.

9. Kudo S, Tamura S, Nakajima T, Yamano H, Kusaka H, Watanabe H. Diagnosis of colorectal tumorous lesions by magnifying endoscopy. Gastrointest Endosc 1996;44:8-14

10. Magazzu G, Bottani M, Tuccari G, Bottari M, Tuccari G, Arco A, Pallio S, Lucanto C, Tortora A, Barresi G. Upper gastrointestinal endoscopy can be a reliable screening tool for celiac sprue in adults. J Clin Gastroenterol 1994;19:255-8.
11. Mauriño E, Capizzano H, Niveloni S, Kogan Z, Valero J, Boerr L, Bai JC. Value of endoscopic markers in celiac disease. Dig Dis Sci 1993;38:2028-33.

12. Morishita T, Asakura H, Miura S. Magnifying endoscopic findings of the duodenum in a case of intestinal lymphangiectasia. Gastroenterol Endosc 1981;23:133-41.

13. Morishita T, Kamiya T, Akagi K. Magnifying endoscopy of the upper gastrointestinal tract in Japan and its application in olive oil tolerance test. Acta Gastroenterol Bol 1982;2:115-20.

14. Oderda G, Forni M, Morra I, Tavassoli K; Pellegrino P; Ansaldi N. Endoscopic and histologic findings in the upper gastrointestinal tract of children with celiac disease. J Pediatr Gastroenterol Nutr 1993;16:172-7.

15. Olds G, McLoughlin R, O'Morian C, Sivak MV. Celiac disease for the endoscopist. Gastrointest Endosc 2002;56:407-15.

16. Ooba T, Doi T, Kobayashi H. A case suspected of celiac disease [abstract]. Nippon Shokakibyo Gakkai Zasshi 1984;81Suppl:2473.

17. Sakazaki S, Toudou T, Kitamura T. A case of chronic intestinal pseudo-obstruction (CIP) syndrome suspected of celiac sprue. Nippon Shokakigeka Gakkai Zasshi 1983;16:2129-33.

18. Stevens FM, McCarthy CF. The endoscopic demonstration of celiac disease. Endoscopy 1976;8:177-80.

19. Tada M, Misaki F, Kawai K. Endoscopic observation of villi with magnifying enteroscopes. Gastrointest Endosc 1982;28:17-9.

20. Yamagata S, Ishikawa M, Yamagishi G. Case of primary sprue followed by reticulosarcoma. Gastroenterol Jap 1966;1:1-4. 